\title{
Discourse, Critique and Subject in Vocational Language Education in Germany: An Outline of the Concept of Critical Foreign Language Didactics
}

\author{
Łukasz Kumięga \\ Silesian University of Technology
}

DOI: http://dx.doi.org/10.18778/1733-8069.16.4.07

\section{Keywords:}

foreign language

didactics, Critical

Discourse Analysis,

post-Foucauldian

discourse

analysis, subject

formation, forms of

subjectification

\begin{abstract}
The paper offers an attempt at including the critical-discursive perspective in the reflection on vocational language education in Germany; its aim is to outline a base for critical foreign language didactics drawing on the critical and post-Foucauldian discourse analysis. The first part of the paper forms a reconstruction of the enmeshment of vocational language education in a number of contexts (political, migrational, and integrative). Constituting a transformative variant of language didactics and examining vocational language education, critical foreign language didactics will be perceived as a research program pertaining to the reflection on education and pedagogical activity (under the framework of critical pedagogy), teaching and learning (from the standpoint of the critical trend in general didactics), and language education and its specificity within teaching and learning particular languages (in the context of foreign language didactics). The final part of the paper will present methodological implications by indicating potential directions for - and levels of - vocational language education analysis. It will also offer an attempt at their further clarification aimed at a critical analysis of subject formation and forms of subjectification.
\end{abstract}

Łukasz Kumięga - linguist, discoursologist, interested in relationships between language and social processes. Assistant professor at the Institute of Education and Communication Research of the Silesian University of Technology, director of the Academic Centre of German Language and Culture in Gliwice. Author of a monograph on street demonstrations of extreme right-wing movements in Germany, co-editor of multi-author monographs from the area of interdisciplinary relationships of linguistics with other humanities and social sciences. Currently conducting research at the intersection of language, discourse, education and migration.

\section{Contact details:}

Silesian University of Technology

Institute of Education and Communication Research

Hutnicza 9-9A, 44-100 Gliwice

email address: Lukasz.Kumiega@polsl.pl 


\section{The Contexts of Vocational Language Education in Germany}

\begin{abstract}
Amadeus Hempel, a member of the board of IBH (Intercultural Education Hamburg), believes that politics is currently very much interested in making refugees quickly undertake employment, and not in supporting them on their way to university. It is indicated by the regulation on vocational language support based on the example of the German language ('Verordnung über die berufsbezogene Deutschsprachförderung'), abbreviated as DeuFöV, which has been in force for a solid year now. DeuFöV courses are to increase the refugees' chances on the labor and training markets. Hempel sees it as follows: half a million of people ought to be promptly incorporated into the labor market. ${ }^{1}$
\end{abstract}

The cited passage, concerned with German language courses in the vocational context, points to several issues that are crucial for vocational language education ${ }^{2}$ in Germany. First and foremost,

\footnotetext{
1 "Cramming for the dream of university studies," Marianne Wellershoff, 2 Sept. 2017, Spiegel Panorama, https://www.spiegel. de/panorama/gesellschaft/fluechtlingsheim-am-grenzweg-safouh-hussain-macht-die-abschlusspruefung-im-sprachkurs-a-1165734.html, author's own translation). "IBH-Vorstand Amadeus Hempel meint, dass es in der Politik inzwischen ein großes Interesse daran gebe, Flüchtlinge eher schnell in Arbeit $\mathrm{zu}$ bringen, als sie beim Weg ins Hochschulstudium zu unterstützen. Indiz ist für ihn die "Verordnung über die berufsbezogene Deutschsprachförderung," kurz DeuFöV, die seit gut einem Jahr in Kraft ist. Diese DeuFöV-Kurse sollen die Chancen der Flüchtlinge auf dem Arbeits- und Ausbildungsmarkt verbessern." Hempel sieht es so: “Eine halbe Million Menschen soll schnell in den Arbeitsmarkt integriert werden."

${ }^{2}$ As an element of both language education and education as such, vocational language education will denote on the operationalizational level of an offer of courses implemented under the above-mentioned resolution on the vocational language support based on the example of the German language ("Verordnung über die berufsbezogene Deutschsprachförderung"). On the conceptual level, its particular determinant will be preparation of migrants for entering the (specifically understood) labor market and, by the same token, it will denote the realization of a specific vocational discourse immersed in the development of language competencies in response to defined and empirically verified needs (cf. Vogt 2011; Huhta et al. 2013).
}

it is about its enmeshment in the political context, which in the case of Germany is tinged with specifically understood multiculturalism. There is nothing revelatory about this observation. What is cognitively interesting, however, is the reconstruction of mechanisms of the said enmeshment. Education is, has been, and will always be an element of some logic of a political nature. In the framework of vocational language education directed at refugees - or, more broadly, migrants - this logic appears to play one of the key roles. It determines the preferred direction for the development of the vocational language offer through being firmly anchored in state institutions (e.g. the Federal Office for Migration and Refugees, BAMF) and, what is essential, it remains in line with the expectations of the greater part of the host society, which needs to be linked with the labor market. The strong feedback loop especially in the context of research on integration between the vocational language education and the labor market is not without significance for various stages of the implementation and execution of language education. Apparently, it is the labor market (specifically understood, i.e. in neoliberal categories) that will determine the concepts and contents of language education. There is nothing wrong about it as long as such a perspective does not become devoid of nuance, and the recipients of the variety of designed solutions - together with their accompanying migrational, cultural, humanitarian or, finally, political contexts - do not assume the character of a silent voice. Consequently, vocational language education takes the form of an instrument for specifically understood integration. This wording denotes a change in perspective with regard to the critique

On the level of the field of study, vocational language education is embedded in the framework of reflection, concept and program solutions of foreign language didactics, which, in this context, will require to be included in discursive and critical perspectives. 
of various types of education, because it concerns not only the reconstruction of the 'hidden curriculum' (cf. e.g. Stankiewicz and Żurek 2016) - a phrase that is popular in the critical reflection on language education and stems to a large extent from the attitude of those teaching and learning - but also the critical reflection on all elements of education, including the concepts and contents of education as well as, in particular, their effects, for instance those connected with the construction of specific subjects of education. It also involves critical reflection on its enmeshment in broader discourses, not only those of a political and economic character. Vocational language education as well as integration which is linked with it closely - both of interest in this paper - are constructed by these discourses. At this point, in connection with integration, it is worth mentioning four dimensions of integration in the context of migration. Yildirim-Krannig (2014) distinguishes: the cognitive-cultural dimension (comprising knowledge of the country of origin language, the host country language - here: German, and the use of language in everyday life); the structural dimension (school diplomas, including vocational schools certificates, occupation, economic situation on the labor market, including professional status, unemployment, housing situation); the social dimension (related to identification with the country of origin and the host country, mindset with regard to the change of citizenship, intention to return to the country of origin); and the community dimension (crime rates, health indicators, recognition of values and norms of the host country, and social distance). These considerations help to understand changes in the attitude to (broadly understood) language education in Germany as well as the specificity of vocational language education. The changes mostly concern moving away from language education predominantly 'serving' the cognitive-cultural in- tegration ('integration courses' directed at everyday communication and realized up to B1 level on the scale of the Common European Framework of Reference for Languages) and approaching multi-dimensional vocational language education that partly overlaps the structural, social, and community integration. This involves topics such as occupation, identification with the country of origin and, in particular, with the host country, as well as - importantly for this paper - recognition of values and norms of the host country. In the context of the notion of integration, it is worth considering in more depth both this process and the shift, observable in the literature, toward promoting another notion, i.e. inclusion (cf. e.g. Firkowska-Mankiewicz 2012; Gębal 2018), as it not only forms a nominalization strategy, but also expands the reflection on the very processes of integration. This is related to a change of perspective consisting in moving away from the focus on deficits of persons with a migration background from the point of view of the system of the host country, toward a collective creation of changes; a new, engaging, and common quality, and reduction of differences, with the participation of host communities as well as persons with a migration background. On the level of concept and on the level of implemented content, vocational language education - forming the main area of interest of this paper - appears to be distant from the modern inclusive approach which functions in Germany within postulative and program discourses of a certain part of the academia. Possibly, the so-called migration crisis of 2015 that forms another - and probably crucial - context of vocational language education in Germany exerted, is still exerting, and will continue to exert influence on a new configuration of these discourses, all the more so because crisis situations (or, to fit in with the neoliberal discourse: 'challenges') will always indicate a redefinition of various assumptions and 
concepts, including a potential opportunity for redefining them productively.

To sum up, vocational language education in Germany is intertwined with a number of factors: political, when the discussion deals mostly with state institutions that create and implement language policy; migrational, when it concerns the influence on managing the so-called migration crisis, and integrative (more broadly: inclusive), when it is about the logic and strategies of including migrating persons into the education system and labor market, among others. The fact that this paper starts with an illustration of a specific empirical area (vocative language education in Germany) and its broad contextualization is connected with the critical-discursive approach, which is preferred in this area as a research program due to its problem-centric dimension. In the following part of the paper, vocational language education will be placed within the framework of foreign language didactics, with all its indispensable clarifications and modifications. This is aimed at posing questions about the possibility and validity of its broad opening for critical-discursive reflection, and drawing the foundation for critical foreign language didactics understood as a research program.

\section{Language Education Within Academic Discourse: Critical Pedagogy, Critical Didactics, and Foreign Language Didactics}

This short introduction to the problems of vocational language education in Germany demonstrates its complexity, entanglement in a number of contexts, and potential for critical consideration. One might ask about whether academic disciplines, subdisciplines or interdisciplines that explicitly or implicitly establish various forms of education as the subject of their studies and debates have at their disposal the tools to facilitate capturing its multidimensionality and openness to reflection of a critical character. In the literature one can come across at at least three such areas: critical pedagogy, general didactics in its critical variant, and, sporadically, foreign language didactics.

Let us begin with pedagogy. Here it is necessary to specify the reason for including it in the reflection on vocational language education, which might be sought not only in references to critical tradition present within its framework (cf. Gębal and $\mathrm{Ku}$ mięga 2020). The relationships between vocational language education and pedagogy become visible when one exits the level of formal language education and ventures into areas directly influencing the civic orientation and the personality-related development of the learners. This paper's author takes the view that the content of vocational language training also has a pedagogic - i.e. educational - dimension. To go one step further, it imposes, smuggles, or cements certain world views, including (which needs to be particularly emphasized here) the views connected with integration and, more broadly, inclusion. Pedagogy provides a number of concepts when it comes to integration and inclusion, which clarifies its relationships with vocational language education even more.

Thus, pedagogy is essential when seeking inspiration for a critical reflection on vocational language education. Reflection on approaches from the field of pedagogy should begin with the observation that they have a multi-vocal character. Radical pedagogy, critical pedagogy, liberation pedagogy, emancipatory pedagogy, pedagogy of resistance, or postmodern pedagogy are all areas which bring nuance to 
various aspects significant for the critical perspective, where stress is placed on social change, economic or cultural reproduction, dominant culture, government, language, ethics, violence, resistance, exclusion, simulacrum creation, rational subject or "subject positions" (cf. Szkudlarek 2010).

The topic of vocational language education undertaken in this paper and the intention to subject it to critical reflection require an important reference point in the form of critical pedagogy, which stems from attempts to formulate the directions for the critique of education, and which will form the background for considerations on the subject of foreign language didactics in its critical variant postulated in this paper. Drawing mostly from the achievements of American pedagogy, Szkudlarek (2010:12-16) distinguishes three major schools of critical thinking in the education context: conservative (postulating a canon of basic notions and reading matter connected with the cultural inheritance of the West); liberal (related to the demands for freedom, individualism, and creativity of the learners); and change-oriented (referred to in other studies as transformative, cf. Klus-Stańska 2018:187), concerned with exposing those aspects of education which prevent or hinder the said change. The second crucial issue will be the perception of education itself within critical pedagogy. Szkudlarek (2010 as cited in Giroux 1983) interprets it in terms of social system reproduction within economic, cultural, and state structure reproduction. The economic reproduction in the context of education is embedded on two levels. Firstly, on the level of public curriculum, which is related to adapting the learners to the labor market. On the level of the 'hidden curriculum' (which is the key problem of critical pedagogy in this variant), one is dealing with the ideology justifying the public curriculum.' This denotes justification for the "life subjected to the existing authorities, their rationality and their interests" (Szkudlarek 2010:18) that - importantly for the critical trend - is 'sold' in this viewpoint as something natural or obvious. The goal is to unmask the vision of the socio-economic reality constructed as obviousness. In the perspective delineated in such a manner, teachers will be the representatives of the system, while learners will be its passive recipients.

The second variant of reproduction, known as cultural reproduction, uses the terms of common (national) culture, dominant culture, and culture of silence. In the education context, it is the government that will form the element which determines the dominating culture, dictating the definitions of the world and identity. The 'silencing' of other cultures will take place by way of a 'symbolic violence' as described by Pierre Bourdieu. The third of the specified types of reproduction, namely the state structures reproduction, forms an intermediate variant, combining economic reproduction with cultural reproduction.

It follows from the above description that in the context of education the system will determine the economic reproduction more strongly than the cultural reproduction. These models will serve as an invitation to capture and describe the mechanisms of broadly understood social reproduction within the education context. Hereby arises a question about (social) change, significant for the concept having the critical background that falls into the area of transformative trend. Szkudlarek (2010) reconstructs several essential transitions in understanding and implementing the direction of this change: empathetic identification with the dominated party, creating and putting into public circulation the language of education critique, creation of the so-called 
'language of opportunities,' language of hope, turning the category of resistance into a new perspective in critical pedagogy, connecting the category of resistance with the learners, associating the opportunity for system change with the teachers, developing critical competence, liberating education.

These considerations can be supplemented with the critique of the critical approach in pedagogy, as it might be discussed in terms of creating a pretence of emancipation and, more importantly, establishing practices which facilitate the avoidance of awareness of such appearances, as well as - what is crucial - reproducing certain (often implicitly defined) ideological interests, with all of the above outfitted with a not entirely clear label of criticality. Such a reflection, especially in the times of negation of modernism, sends one back to the question about whether it is possible for critical pedagogy, and pedagogy itself, to exist. The postmodern pedagogy of Giroux (cf. Szkudlarek 2010) becomes a certain capstone for all the 'turns' in pedagogy with an implicitly or explicitly critical slant.

The reconstruction of critical pedagogy and its key elements (the critique of theory and practice of education, its hidden assumptions and curricula, unmasking myths and appearances of education) demonstrates how complex and how entangled in multifarious contexts the whole process of education is. What is especially interesting and significant for this paper is the economic context, i.e. the treatment of education as an element of economic reproduction, currently centered around neoliberalism, together with the paradoxes of this reproduction. It is evoked here because it opens up a possibility to think about education in a critical perspective. Moreover, it introduces critical thought to the reflection on education in the context of other disciplines, thereby heading even further toward establishing detailed contexts and elements of vocational language education. One such discipline will be general didactics, which - due to academic and conceptual ties with critical pedagogy - opened up to the critical approach.

General didactics prompts the reflection on teaching and, increasingly more often, also learning. Thus, in relation to pedagogy, it is a discipline that narrows down the area of research, if pedagogy is to be defined broadly as the academic discipline of pedagogical activity. Klus-Stańska (2018) distinguishes three paradigms in the context of general didactics: objectivist (normative didactics, instructional didactics, neurodidactics); interpretative-constructivist (humanist didactics, constructivist didactics, and connectivism); and transformative (critical and libertarian didactics). Critical didactics anchored in the transformative paradigm, i.e. the paradigm seeking a social change, will spring from the critical pedagogy recounted above. In the Polish academic sphere, it is a novel discipline, reacting to the prolonged stagnation in including the specifically understood critical consideration into the reflection on school or, more broadly, on education. It aims at reconstructing and critiquing school's hidden influence in terms of all elements of education (Klaus-Stańska 2018:202). These elements comprise, in particular: lists of school subjects and school subjects contents imposed by the authorities; learning outcomes, tests, and exams constructed in the curriculum; didactic elements such as the emphasis on verbal activity, the marginalization of technical knowledge, the selection of reading material, focusing the historical content on political issues, individualist-competitive culture of teaching, inculcation to understanding valuable life as based 
on conquering successive formal, bureaucratic levels of the education system, lesson model based on the authority of one person over the others (cf. Klaus-Stańska 2018:203). Summing up this thread, it is possible to assume that material and non-material subjects of the specifically understood reflection within critical didactics comprise: the curriculum, educational contents, educational strategies, and lesson formulas.

Similarly to critical pedagogy, critical didactics - being consistent in perceiving itself as a discipline immersed in the transformative paradigm - will also set change as its goal, stating this change as "rectification of curriculum and saturating students' learning with content and strategies which reinforce their engagement in creating the world that is determined by the critically understood justice" (Klaus-Stańska 2018:207). By the same token, critical didactics becomes connected to ethical issues and, to cite Kwieciński (2007), it postulates "critical alphabetization." Therefore, in this 'rectification' of the curriculum, it will prefer specific contents (human rights, political education, critical reflection on fake news, content related to local communities and school communities) as well as particular strategies [change of communication rules (orientation toward communication), presentation of ambiguities, reinforcement of the idea of debate, critical reading, orientation toward the needs of students and local environments]. In critical didactics, teachers are 'transformative intellectuals.'

The critical trend in general didactics should be appreciated as an important voice, because it invites reflection on various elements of education processes which not only are worth such a reflection, but downright require it. Following the path of seeking critical references and approaching even more closely the main topic of this paper, namely vocational language education, it is necessary to address foreign language didactics, also known as glottodidactics. In the Polish academic sphere, apart from sporadic or implicitly expressed references in this regard, there is a lack of a separate research area which - with all necessary clarifications - would fall into the area of critical pedagogy and didactics, and which might be termed as critical foreign language didactics.

Trends in foreign language didactics can be divided according to the conceptual key (behavioral, cognitive, and constructivist trends) or the methodological key [audio-lingual (audiovisual), communicative, and action-based trends]. Critically observing the development of foreign language didactics, it is possible to notice certain centers of gravity, forced by the theoreticians of this discipline, i.e. the fact that they focus on conceptual issues mostly related to the area of linguistics (in particular, psycholinguistics) and strictly methodological problems ${ }^{3}$. Not to downplay the role of these issues for the discipline of foreign language didactics as a whole, the humanistic reflection, so strongly accentuated within, for instance, pedagogy and general didactics, seems to remain at a stage where it is not yet fully perceived as added value or a certain key conceptual superstructure of this discipline. The situation is, however, changing. The action-centered trend, primarily drawing on constructivism, displays a certain opening onto humanistic topics, including critical ones, and, by the same token, transformative topics, as it postulates equipping the participants of the didactic process with agency immersed in their deep autonomy.

\footnotetext{
${ }^{3}$ Here it is worth adding that, currently, methodology is perceived as a subdiscipline of foreign language didactics.
} 
Moving on to track constructivism, which opens the critical perspective within foreign language didactics, one can find references to that thought. They also indicate, against that background, certain new or newly defined aspects of the didactic process. Żylińska (2009) speaks about it in the context of "constructive didactics of foreign languages," while Lewicka (2007) interprets the glottodidactics process discursively. It is necessary to stress here that the reception of constructivism denotes a significant change of perspective and implicitly falls into the critical or transformative trend. For instance, this applies to the individualization of the learning process and new ways of defining subjects of the education process, including, in particular, those teaching and learning.

One should stop here for a moment to consider Lewicka's (2007) concept, as it introduces the notion of discourse with regard to constructivism. This is an issue significant for this paper and will be discussed in detail further on, in the part outlining the introduction of the category of discourse to the studies on vocational language education with a critical and transformative angle. In Lewicka, the category of discourse is derived from van Dijk (a representative of the socio-cognitive model of Critical Discourse Analysis) and it is defined as a "communicative event" which comprises three elements: cognitive processes, the use of language, and interactions under specific socio-cultural conditions (Lewicka 2007:109-110). According to that concept, discourse is understood through the place where these phenomena of verbal processes are articulated. In glottodidactics with the discursive angle, it denotes the inclusion into its spectrum of the development of the discursively understood "communicative competence," defined as "the ability to participate in the discourse." Here it is necessary to pose the first ques- tion - why is not discursive competence taken into account in this context? Secondly, the limitation of the category of discourse to the process of language learning only (developing the "communicative competence") - an an unmistakably important, yet not the sole element of the whole glottodidactic process - appears not to exhaust its potential, especially when one takes a closer look at theoretical, methodological, and methodical grounds of the interdisciplinarily perceived studies on discourse, including the Critical Discourse Analysis itself. The following part of the paper will move along that trail in search for critically- and, therefore, discursively-oriented foreign language didactics.

A separate topic thematized within the preparation and evaluation of glottodidactic aids is the hidden curriculum (Stankiewicz and Żurek 2016). What is interesting is that the concept of hidden curriculum crops up in various academic contexts, including empirical ones; for instance, it appears in critical pedagogy and critical didactics mentioned above. By way of possessing high critical and interdisciplinary potential, this concept became an important reference point in the context of critical reflection on the subject of the glottodidactic process, although it remains limited only to its selected elements. Stankiewicz and Żurek (2016), drawing on Rylke (1984), define hidden curriculum (with regard to the cultural context of teaching Polish and German as foreign languages) as the attitude of persons responsible for the process of language education (i.e. coursebook authors, teachers, and heads of educational institutions) toward: 1. teaching language content and cultural content (comprising, for instance, education objectives, content selection, methods, approach to teaching); 2. student's culture (manifesting through forms of addressing the student, manners in which their 
country is presented, value attributed to a given culture, etc.); 3. own country's culture (observed in the conveyed image of one's own country, the attitude toward language, cultural achievements, and various cultural communities on the regional, national, or European level).

Thus, the hidden curriculum will be reconstructed in the research process as a certain opposition to the official curriculum. Some doubts arise here. Firstly, it is possible to pose the question about whether the official curriculum itself does not contain certain hidden elements (drawing on the main assumptions of Critical Discourse Analysis, particularly those that relate to language and its relationships with government) and, secondly, whether the reconstructed hidden curriculum is not, to some extent, the effect of the official curriculum. On the other hand, it is doubtless that the problems undertaken in the described area of studies form a significant opening of foreign language didactics to critical trends that reveal a necessity for an interdisciplinary take on the thusly constructed research problem, which could certainly be extended to other elements of the glottodidactic process, going beyond curriculum analyses. ${ }^{4}$

To sum up, within the area of foreign language didactics reconstructed here, one can observe at least three tendencies which are fundamental for the subsequent considerations: firstly, an opening to constructivist trends; secondly, references to the category of discourse; thirdly, following the critical reflection (cf. Kumięga 2020a). They signal a grad-

\footnotetext{
${ }^{4}$ In this context, it is worth turning attention to a separate trend in foreign language didactics, referred to as the reflexive trend (cf. Wilczyńska 1999; Nawracka 2020), as well as to studies which perceive Polish-language glottodidactics as a sphere of ideological and/or inter-cultural conflicts (cf. Zarzycka 2000; Piekot and Zarzeczny 2010).
}

ual opening of this area to the issues very broadly adopted in the context of pedagogy or general didactics. On the other hand, though, they expose their limited occurrence and restriction to the selected elements of the glottodidactic process ${ }^{5}$. In the following part of the text, I will discuss how it is possible to become inspired by the critical-discursive approach: on the one hand, in a broader empirical sphere, related to various planes of language education, including vocational language education, and, on the other hand, in an integrating manner, on the level of theoretical-methodological considerations that combine theories and methodologies crucial to these dimensions. This illustration will apply to vocational language education in Germany mostly due to its strong institutionalization. However, the following considerations can be equally successfully applied to the Polish reality, which is facing migrational processes on an increasingly significant scale. An example of the reflection in this area is the integrative-inclusive glotto-pedagogical model of the didactics of Polish as a second language (dedicated to persons with a migration background or migration experience, cf. Gębal 2018; Gębal and Miodunka 2020), drawing on inter-cultural teaching, multilingualism didactics, pedagogical inclusion and inclusive education, as well as positive education. Polish and German solutions within the framework of academic discourse might become a subject of comparative studies, whereas the strong institutionalization of language education and vocative language education in Germany could form an invitation to reflectional attempts at its implementation in Poland

\footnotetext{
5 This observation is confirmed by Foreign Language Didactics: An Introduction [Dydaktyka języków obcych. Wprowadzenie] (Gębal 2019), which contains references to: modern pedagogical trends, constructivism in foreign language didactics, and the hidden curriculum.
} 
after all the requirements of education comparativism are met.

\section{Critical Discourse Analysis and Vocational Language Education: Theoretical Assumptions}

The author of this paper takes the view that the category merging the multidimensionality of different forms of language education through its integrating character is the category of discourse and its whole theoretical, methodological, and methodical background in the form of (inter)disciplinary studies on discourse, mostly those that draw on Critical Discourse Analysis (CDA) and Post-Foucauldian Discourse Analysis (PDA). Therefore, when considering foreign language didactics in the above-outlined context, one must begin with the category that is crucial for this perspective. Undoubtedly, it will be the category of discourse ${ }^{6}$; a category only seemingly ambiguous, as it will appropriately - i.e. being constructed in connection with specific theoretical traditions - attempt to capture the topics that are important for the analysis of a given empirical area. In this context, Czachur (2020:130-147) distinguishes four ways of understanding discourse within the framework of research practices. Although these ways originate from the Polish-and-German-Studies exploration of discourse, they might be successfully found in other research traditions. They comprise: discourse as thematically interconnected texts; discourse as a series of (media) communicative activities, interaction, and social practice; discourse as a cultural

\footnotetext{
${ }^{6}$ Critical pedagogy follows a similar path, which is pointed out by Śliwerski (2015:500-501): "In the modern critical pedagogy, discourse forms a central notion of the analytical concept of Michel Foucault, in which it is understood as the system of knowledge, concepts or thoughts embodied in the social practices, and taking place in the real world."
}

model/pattern of social communication; discourse as the selection of knowledge and the process of negotiating collective meanings.

Before we present the discursive and critical elements of vocational language education in more detail, it might be worthwhile to devote a moment of time to attempts at determining the scope of foreign language didactics as an academic discipline. It is worth mentioning that in Poland they used to be performed under the framework of 'glottodidactics' (Grucza 1978), originally understood as a certain meta-reflection on the didactic processes in their theoretical dimension? Thus, when trying to establish and better identify the subject of glottodidactics, elements of the so-called glottodidactic system were usually indicated. Referring to the model of communication, Grucza (1978) marked out its three essential elements, namely: teacher, channel (later on replaced by the didactic platform), and student. This demonstrated the interdisciplinary character of glottodidactics, one that combines linguistic reflection with didactic-pedagogical reflection. In his expanded model of glottodidactics, Grucza (1978) went on to distinguish applied glottodidactics (applied research and information) from pure, theoretical glottodidactics (basic research and information). Another glottodidactic system worth mentioning is Pfeiffer's concept (2001). Here, the elements of the glottodidactic system are: educational conditions, teacher, language, student, didactic aids, and methods of language teaching and learning. Thus, in this context one can observe an attempt to specify the elements

\footnotetext{
$\overline{7}$ In modern reflections, the notion of "glottodidactics" is increasingly often treated as the synonym for the term "foreign language didactics" (cf. Gebal 2019). This symbiosis plays a discipline-enhancing role for the whole area of studies on language learning and teaching, reinforcing its academic autonomy.
} 
of the glottodidactic system, which is further on extended to cover social topics such as: objective reality, social environment, school environment, and state education policy, which form a nod to the constructing of the didactic process in a discursive manner, taking into account its social context. In his model, Gębal (2013), following Pfeiffer, perceives glottodidactics broadly, indicating its following elements: those teaching, those learning (the nominalization strategy applied here is aimed at emphasizing the processual character of these two subjects of the glottodidactic model), channel, teacher training, and learner type. The last two elements and, in particular, the final one, will emphasize the identity-related themes important for the critical-discursive perspective and associated with constructing the subject in the glottodidactic process. The social context of this model is complemented by its two other elements, namely state education policy and the idea of multilingualism - one might broader call it the European context which Gębal connects with postulating a particular branch of glottodidactics, i.e. comparative glottodidactics (Gębal 2013).

Therefore, while looking at the individual models of the glottodidactic system, one observes its increasing complexity and broadening contextualization. This paper also heads in this direction, as does the proposition of a critical and discursive interpretation of vocational language education in Germany contained in it, together with the posed questions about critical foreign language didactics.

When mentioning the fundamental aim of approaches described in the literature as critically-oriented, including Critical Discourse Analysis, it is worth going back to one of its main sources of inspiration, namely the so-called critical linguis- tics. It provides information as to the scope of that aim: "Critical linguistics seeks, by studying the minute details of linguistic structure in the light of the social and historical situation of a text, to display to consciousness the patterns of belief and value encoded in the language - and which are below the threshold of notice for anyone who accepts the discourse as 'natural'" (Fowler 1991:67 as cited in Duszak 1998:65). The development of what one might call discursive awareness was, then, the aim of critical linguistics, whose thought is continued by the research program of Critical Discourse Analysis in a number of empirical contexts.

Returning to the question that is fundamental here, namely the possibility to include the critical-discursive tradition in reflections on vocational language education, it is necessary to evoke its main assumptions, which Duszak and Fairclough (2008:15-18) specify synthetically - in a bird's eye view on a number of variants of $\mathrm{CDA}^{8}$ - in the following way:

- "CDA deals with social processes and problems";

- "Discourse is the key factor in the construction of social life";

- "Discourse is an important element of power relations";

- "Critical discourse analysis contains an element of a detailed text analysis."

\footnotetext{
Czyżewski (2013:8) distinguishes the following variants of CDA: "the variant represented by Norman Fairclough; the variant focused around Siegfried Jäger in Duisburg; the variant of "the Loughborough group," initiated by Michael Billig and continued by, among others, Jonathan Potter; social-cognitive variant of Teun van Dijk and the so-called Viennese variant, sometimes called the "discursive-historical" variant, created by Ruth Wodak and her team at the University of Vienna.

${ }^{9}$ In the context of CDA complexity, cf. Kopytowska and Kumięga 2017.
} 
This means that CDA is a research program with the problem-centric slant, drawing on constructivism, stressing the power-forming aspect of discourse and the significance of an in-depth analysis of texts treated in the categories of discursive fragments and traces of broader social processes.

In the course of logical operations, this will denote treating vocational language education as: 1) a social process and problem, which will imply its broad contextualization; 2) discourse which (co)creates the social reality; 3) an element reproducing complex power relations; and 4) the phenomenon that is reconstructed through texts.

As a consequence of the adopted assumptions, one distinguishes three levels of vocational language education in terms of discursive categories:

- the level connected with institutions responsible for vocational language education (the discourse of vocational language education);

- the level connected with non-education institutions, speaking or writing about vocational language education (the discourse about vocational language education);

- the level connected with those teaching and those learning [the discourse of subjects of vocational language education (cf. Kumięga and Nawracka 2020)].

When related to vocational language education together with the distinction of its three levels, CDA assumptions outlined above send one back to the question of the specificity of a particular empirical area that is to be subjected to analysis. This area is the didactic reality in Germany in connection with migrational processes.

\section{The Empirical Context: Vocational- Language Education in Germany}

It is now necessary to have a closer look at the offer of language education in Germany which is directed at immigrants ${ }^{10}$. The main players responsible for the design, implementation, and coordination of the German educational policy - including language education and vocational language education in the context of migration - are the Federal Office for Migration and Refugees (Bundesamt für Migration und Flüchtlinge - BAMF), Foreigners' Registration Offices (Ausländerbehörde), and Employment Offices (Agentur für Arbeit), whereas the fundamental legal act in this respect is the Residency Act of $1^{\text {st }}$ January 2005.

Since 2005, in Germany there has been an offer of 'integration courses' (Integrationskurse), described in this paper as one of elements of language education and oriented at development of competencies in everyday communication. These courses cover 300 hours of a basic language course, 300 hours of an extended language course (ultimately leading to reaching B1 level on the scale of the Common European Framework of Reference for Languages), and 100 hours of an orientation course, focused on social, political, and cultural aspects of the life in Germany. On their completion, participants are awarded a certificate of the integration course (Deutschtest für Zuwanderer-DTZ). Additionally, there is an offer of special integration courses, e.g. for women, parents, youths, alphabetization courses for the illiterate (1,000 hours), or intensive courses (430 hours).

\footnotetext{
${ }^{10}$ The information below is the effect of the analysis of documents of the Federal Office for Migration and Refugees, available on: https://www.bamf.de/. They had been originally presented for the purposes of a different project (Kumiegga and Nawracka 2020).
} 
Integration courses are supplemented by vocational German language classes (Berufsbezogene Deutschsprachförderung) - in this paper referred to as vocational language education - conducted on levels: A2, B2, C1, C2 (currently extended to 600 hours) under the framework of basic courses which combine vocational education with everyday communication, or the framework of specialized courses dedicated to, e.g., various medical professions.

Another program from this area is ESF-BAMF, financed by the European Social Fund. It covers language classes, company visits, specialized courses, and vocational training (730 hours), and it is an example of a closer association of the German language learning with vocational education.

To sum up, the offer of German integration courses and vocational education courses is, on the one hand, characterized by a strong institutionalization and structure, which undoubtedly forms its advantage. On the other hand, it is still possible to point to certain disadvantages of such solutions, which are of a multithreaded nature: associations with symbolic violence by way of obligatory participation of the selected groups of immigrants in the courses; standardization in the area of testing; cultural heterogeneity and, frequently, educational heterogeneity of language groups, especially those which participate in integration courses; or unification manifested as forcing a designated image, for instance of an immigrant, in the didactic aids. While treating integration courses and vocational language courses as a specific area of intercultural communication, it is also worth addressing here the academic reflection undertaken in Germany as early as in the 1990s, presenting and characterizing communication between native and non-native users of the German language in terms of linguistic consulting (Germ. sprachliche
Beratung). Using the tools of conversation analysis, Czyżewski (1996) examines a specific conversation ${ }^{11}$ and establishes transition to authoritarian communication as one of the potential determinants of this type of communication. He connects it to a claim to power on the part of the native user of a language. Such an interpretation, immersed in a specific communicative situation, can also be translated to other areas of the didactic process, which inceptively invites a reflection of a critical nature. Czyżewski's paper comes from a multi-author monograph that analyzes the said conversation from numerous research perspectives, which also forms a specific invitation of a methodological character, demonstrating the added value of interdisciplinary approaches. They open new potential manners of practicing such a type of research - from a reduction of possible interpretations, to juxtaposing them as equivalent, to searching for a third course, consisting in an explication of the unspoken elements which are related to both research subject and research process itself (cf. Koller 1999).

\section{Critical and Post-Foucauldian Discourse Analysis and Vocational Language Education: Theoretical and Methodological Assumptions ${ }^{12}$}

To return to the main assumptions of Critical Discourse Analysis, one should note the social dimension of vocational language education in Germany (implemented mainly through the program of $\mathrm{Be}$ rufsbezogene Deutschsprachförderung). This can be achieved through treating all its products (by the state, publisher, or individual) in terms of Foucauld-

\footnotetext{
${ }^{11}$ It is a conversation between Kalu, an African postgraduate student, and Bert, a German revisor. Its subject matter is Kalu's doctoral dissertation.

${ }^{12}$ Cf. Kumięga 2020b.
} 
ian urgence, i.e. as a specific social breakthrough situation. Although the 'migration crisis of 2015' itself will form an important element here, no less important are the questions related to the influence of migration on the German labor market. Thus emerges a specific subject for analysis - when reconstructed on the example of selected texts/discursive fragments, it can be confronted with the following research questions, influenced by critical linguistics and, consequently, Critical Discourse Analysis (cf. Fowler et al. 1979; Duszak and Fairclough 2008):

- Question 1: What "patterns of belief and value encoded in the language" are visible or invisible in vocational language education in Germany?

- Question 2: What patterns are absent or are (un)consciously ignored?

- Question 3: Do any preferred (or perhaps imposed) patterns emerge? Do they have or can they possibly have violent character?

One cannot put the question about beliefs and values encoded in the language - in this case, in vocational language education in Germany - at the center of the analysis without confronting this thought with phrases recurring in a variety of social contexts, including the context which is the main focus of the following part of the paper. These are phrases such as: "knowledge-based economy," "people management," "resources management," "self-management" (cf. Stachowiak 2013). Therefore, in thinking about a serious reflection on vocational language education in Germany, and with respect to critical pedagogy presented above, one cannot pass over the aspects related to the social system reproduction within economic reproduction, and connected with orientation toward adapting learners to the labor market. Here it is necessary to return to one methodological issue. Although Critical Discourse Analysis favored in this paper provides much scope for reflection and numerous research tools (cf., e.g., Reisigl 2010), its empirical focus on the discourses "to the right from the right"- assuming that this labeling is still currently functional - can limit a sharp and precise insight into a variety of products of economic discourses, including, in particular, the neoliberal discourse within vocational language education in Germany. Therefore, it appears indispensable to supplement Critical Discourse Analysis with the post-Foucauldian perspective ${ }^{13}$, which will be executed on two levels: firstly, I will point to the added value of the category of governmentality and studies which refer to this value in the reflection on vocational language education in Germany, and, secondly, I will define the category of the subject, which will be aimed at specifying CDA as a critical analysis of subject formation and forms of subjectification.

Treating vocational language education in terms of social system (re)production, it is worth referring to the Foucauldian notion of governmentality and the development of governmentality studies (in this regard cf. Czyżewski 2009; Foucault 2012; Stachowiak 2013; Nowicka 2016). As a term formulated by Foucault in the late 1970s, 'governmentality' denotes a specific form of government that explains global processes of creating the social order. Governmentality studies concern neoliberal governance, implemented e.g. through socio-political programs or therapeutic activity, whose essence lies in 'governing' the population through transforming individ-

\footnotetext{
${ }^{13}$ In the Polish pedagogy, reference to the post-Foucauldian perspective can be seen in Ostrowicka 2017.
} 
uals into self-governing individuals. In this trend - importantly, also an empirical one - there appears a category which (in the context of the intended analyses of vocational language education that are to take into account its social-, knowledge-, powerand, preeminently, subject- and identity-creative character) should become a relevant reference point, an inspiration for further clarifications, or even a thought figure. I am speaking here of the category of 'entrepreneur of the self' who, in Sennett's view (1998), is a 'flexible capitalist.' Drawing on literature, Stachowiak (2013:144-145) outlines the major determinants of 'self-entrepreneurship':

- "entrepreneur of the self is to be the culmination and, simultaneously, a characteristic feature of the theory of human capital, which appeared in neoliberalism of the American type";

- "entrepreneur of the self is to make independent educational investments into their own human capital, is to be eager to multiply them and hope for the future profits from self-management";

- "entrepreneur of the self recreates a specific management art (...), taking over onto themselves a significant part of the efforts of erstwhile supervisors, administrators, and management engineers, but also learns to be oriented toward activities which are possible to express through economically understood effectiveness;"

- "Currently, an aspect of entrepreneur of the self's activity is to adopt a managerial attitude toward individual and collective efforts. It means a highly rationalized practice that can be controlled, planned, and calculated while being harmonized with the society organized to resemble an enterprise, in which all ambitions, goals, and opportunities of individuals are reinterpreted in economic categories."

Thus, 'governmentality' is a particular form of governance, a form of specific control and regulation of human behaviors, whereas 'self-entrepreneur' is a particular form of the subject, and vocational language education is a place where this form of governance and this form of the subject can be discursively and non-discursively reproduced. The aim of the analysis delineated in such a manner will be, therefore, to focus on manifestations and scope of this form of governance and this model of the subject. Even the perfunctory analysis of the vocational German-language teaching coursebooks themselves ${ }^{14}$ allows one to outline their discursive centers of gravity:

- emphasis on greater social mobility of individuals;

- emphasis on the increasing significance of individual achievements and individual education paths;

- lower significance of the social origin and status;

- more emphasis on individual behaviors (as opposed to behaviors shaped by social groups);

\footnotetext{
${ }^{14}$ When examining the policy of German publishers, one can distinguish three types of didactic aids, i.e. coursebooks concurrently 'attending to' the specialist language and general language in everyday, colloquial use; communicative aids and activity-oriented tools directed at developing strategic competencies in the area of specialist communication without particular regard for specific variants of specialist languages; and, finally, specialist materials dedicated to particular occupations, e.g. medical. On the level of state institutions as well as publishing houses themselves, there is a visible preference for general language education oriented at broadly understood professional needs.
} 
- larger individual responsibility and freedom of choice;

- self-control and self-fulfillment. ${ }^{15}$

At this point, one allows CDA, supplemented with the post-Foucauldian perspective, to don the robes of analyses interested in the category of the subject. In a direct reference to the 'entrepreneur of the self,' the subject will be understood in Foucauldian terms, i.e., as noted by Nowicka (2016), not as "an agent of an autonomous, free action, but as a personage that is subjugated and, therefore, subjected to external and internal control." Beside knowledge and power, the subject will be one of the key aspects of the Foucauldian understanding of discourse. Returning to the above-mentioned ways of understanding the category of discourse in research practices, this perspective will fall into understanding discourse as "knowledge selection and process of negotiating collective meanings" (Czachur 2020:138).

To consider in more detail turning the subject into one of the key topics of the intended research, it is necessary to clarify the ways in which it is to be understood and methodologically represented. Two categories will become helpful to this end, namely subject formation and forms of subjectification. Forms of subjectification concern the manner in which people perceive, experience, and interpret themselves and others on the empirical-factual level. Subject formation is a term which aims at describing the way in which people learn certain practices or programs on the normative-program level. Thus, forms of subjectification are what lies at the base of cognition, while subject formation denotes what is

\footnotetext{
${ }^{15}$ Own elaboration based on experiences with conducting vocational German language courses in ASG Bildungsforum language school in Düsseldorf, under the program of Berufsbezogene Deutschsprachförderung on the basis of the coursebook FOKUS DEUTSCH, Cornelsen Verlag.
}

subordinated in the meaning of a manipulated, reified subject (cf. Bührmann 2007:642). Returning to the category of 'entrepreneur of the self,' Bührmann (2012) poses the question about whether it is possible to treat it 'solely' in terms of subject formation, or also in terms of forms of subjectification. Together with the posed question, the distinction mentioned here has consequences for the planned research insofar as, remaining faithful to the broad contextualization - also methodological - assumed above, and treating teaching aids (coursebooks) as products of vocational language education discourse and a point of reference, analyses of such a type should take into account two phases: pre-coursebook and post-coursebook. Hence, the analysis of subject formation will concern, apart from teaching aids, also the discourse of European institutions (the Council of Europe), state institutions (e.g. BAMF), academic and non-governmental bodies, publishing houses (the pre-coursebook phase); and public discourse on vocational language education, including, in particular, media discourse (pre- and post-coursebook phases). The analysis of forms of subjectification will pertain to the examination of language instructors' discourse and the examination of courses participants' discourse (participant observation, group discussion, survey studies, interviews), i.e. it will be connected with the post-coursebook phase.

The analysis of subject formation will treat the 'entrepreneur of the self' as a thought figure, intended to verify empirically the ways of constructing subjects in vocational language education. What is interesting and symptomatic for the analyses of that type is subject formation by way of using binary oppositions ("preferred" subject vs. "deficient" subject), implemented in the context of governmentality along the criteria of failure and success, which is a determinant of the political economy understood 
as the extension of a state's national interest (cf. Nowicka 2016). The analysis of forms of subjectification translates into asking questions about adopting, redefining, or rejecting the reconstructed and preferred model of the subject by those teaching as well as those learning. In the context of 'self-entrepreneurship,' this will be a doubly significant question, as it also addresses the question connected with 'adopting' the preferred model of the subject perhaps not in terms of 'self-discovery' (Germ. Selbstfindung), but as 'self-invention' (Germ. Selbsterfindung), which will contain the components of manipulation and fiction (cf. Bührmann 2007:69).

\section{Critical Foreign Language Didactics: Perspectives}

The above considerations were aimed at a wide contextualization of vocational language education in Germany in relation to the multi-perspective character of the discourse category, with which this education is being connected (indicating its political, social, economic, and integrational-inclusive character, as well as its knowledge-, power-. subjectivity-, and identity-forming character). Drawing on the critical-discursive and post-Foucauldian approaches, it led the author to profile the discourse analysis as a tool for reconstruction of subject formation and forms of subjectification, associating them with governmentality as a specific form of power/ governance and the 'entrepreneur of the self' as a thought figure. Coming back to the reflections of a discipline-related character, it demonstrated the presence of critical reflection in areas such as critical pedagogy and critical general didactics, and revealed scarce references to this perspective in the area of foreign language didactics. In the context of the latter, a question arises as to the possibility of applying critical foreign language didactics. It is pos- sible under several key assumptions. Firstly, when the category of discourse operating along the conceptual triad of government-knowledge-subject ${ }^{16}$ is included in the glottodidactic reflection; secondly, when all institutions and players engaged in vocational language education, as well as all elements of the didactic process, are treated as entities (re)producing social systems; and, thirdly and lastly, when critical foreign language didactics is treated as a research program of a transformative character. This means that critical foreign language didactics will form another critical voice in the discussion on education. It will pose questions about the boundaries of government and, in its vocational language context, it will reverse the trend of the critical pedagogy oriented at the critique from the liberal perspective, revealing its traps and limitations. This critique will not be concerned with total criticism, demanding absolute rejection of vocational language education based on the neoliberal discourse, but it will turn attention toward: extricating the nuances of that discourse, the necessity to notice its 'naturalization,' and the need to allow for other, probably less 'popular' perspectives in this extremely significant educational context. Objections regarding the creation of the pretence of emancipation, present in the critical commentary on the critical trends, will become more nuanced along with the references to the Foucauldian understanding of the critique whenever the discussion will be concerned with how not to be governed like that, by that, in the name of those principles, with such an such an objective in mind and by means of such producers, not like that, not for that, not by them (Foucault 1990:36-39, as cited in Nowicka 2016). As an important consequence, the

\footnotetext{
${ }^{16}$ The multiperspectivity of the category of discourse and the multiplicity of its definitions will also open a possibility to construct it differently for the needs of a further broadening of this viewpoint within research on various forms of education.
} 
aforesaid critique might be conducted on three levels: textual, social, and prognostic, i.e. firstly, when it is related to revealing inconsistencies or internal contradictions of the analysed texts while simultaneously pointing out their functions; secondly, when it reconstructs manipulative and persuasive strategies in discourses; and, thirdly, when it identifies "moments problematic from the point of view of government" (cf. Kopytowska and Kumięga 2017). In this triad, one can discern a special function of critical foreign language didactics. Treating all elements of vocational language education seriously and demonstrating the effects of subject(s) formation, as well as reconstructing forms of subjectification in its context, the field faces the questions connected with integration and can possibly reveal the ways of discursive subject formation in order to come closer to the inclusive approach postulated in some academic circles. Activity on the discursive level in its inclusive dimension might turn out

\section{References}

Bührmann, Andrea D. 2007. “Soziale Arbeit und die (Trans-) Formierung moderner Subjektivierungsweisen." Pp. 59-64 in Foucaults Machtanalytik und Soziale Arbeit. Eine kritische Einführung und Bestandsaufnahme, edited by R. Anhorn, F. Bettinger, and J. Stehr. Wiesbaden: VS Verlag für Sozialwissenschaften.

Bührmann, Andrea D. 2012. "Das unternehmerische Selbst: Subjektivierungsform oder Subjektivierungsweise." Pp. 145164 in Diskurs, Macht und Subjekt: Theorie und Empirie von Subjektivierung in der Diskursforschung, edited by R. Keller, W. Schneider, and W. Viehöver. Wiesbaden: VS Verlag für Sozialwissenschaften.

Czachur, Waldemar. 2020. Lingwistyka dyskursu jako integrujacy program badawczy. Wroclaw: Oficyna Wydawnicza ATUT. more effective with regard to political and media discourse oriented at the statistics of success rate of language exams than activities directed at the modification of exam requirements and standards (to the effect of lowering them) or the development of texts dedicated to selected groups of persons with a migration background (cf. certificate of the integration course Deutschtest für Zuwanderer - DTZ).

To conclude, critical foreign language didactics will bridge an important gap in the humanistic reflection on vocational language education, significantly extending the insufficient presence of references to this tradition of thinking in foreign language didactics. The perspectives illustrated in this paper constitute the first attempt at drafting the foundation for foreign language didactics profiled in such a manner, and they form an invitation to further, indepth reflections that deal with this very complex academic and empirical area.

Czyżewski, Marek. 1996. “'Das versteh ich nich.' Grenzen der Argumentation und andere kommunikative Merkmale in der sprachlichen Beratung." Pp. 25-36 in 'Jeder Deutsche kann das verstehen.' Probleme im interkulturellen Arbeitsgesprach, edited by R. Kokemohr and H-Ch. Koller. Weinheim: Deutscher Studien Verlag.

Czyżewski, Marek. 2009. “Między panoptyzmem i rządomyślnością - uwagi o kulturze naszych czasów." Kultura Wspótczesna 2:83-95.

Czyżewski, Marek. 2013. "Teorie dyskursu i dyskursy teorii." Kultura i Społeczeństwo 2:3-25.

Duszak, Anna. 1998. Tekst, dyskurs, komunikacja międzykulturowa. Warsaw: Wydawnictwo Naukowe PWN. 
Duszak, Anna and Norman Fairclough. 2008. "Wstęp: Krytyczna analiza dyskursu - nowy obszar badawczy dla lingwistyki i nauk społecznych." Pp. 7-29 in Krytyczna analiza dyskursu: interdyscyplinarne podejście do komunikacji społecznej, edited by A. Duszak and N. Fairclough. Cracow: Universitas.

Firkowska-Mankiewicz, Anna. 2012. Edukacja właczajaca zadaniem na dziś polskiej szkoły. Warsaw: Ośrodek Rozwoju Edukacji.

Foucault, Michel. 1990. “Qu'est-ce que la critique?” Bulletin de la Société Française de Philosophie 2:35-63.

Foucault, Michel. 2012. Narodziny biopolityki. Wykłady z Collège de France 1978/1979. Warsaw: Wydawnictwo Naukowe PWN.

Fowler, Roger. 1991. Language in the News: Discourse and Ideology in the Press. London: Routledge.

Fowler, Roger et al. 1979. Language and Control. London: Routledge \& Kegan Paul.

Gębal, Przemysław E. 2013. Modele ksztatcenia nauczycieli języków obcych w Polsce i w Niemczech. W strone glottodydaktyki porównawczej. Cracow: Księgarnia Akademicka.

Gębal, Przemysław E. 2018. Podstawy dydaktyki języka polskiego jako drugiego. Podejście integracyjno-inkluzyjne. Cracow: Księgarnia Akademicka.

Gębal, Przemysław E. 2019. Dydaktyka języków obcych. Wprowadzenie. Warsaw: Wydawnictwo Naukowe PWN.

Gębal, Przemysław E. and Łukasz Kumięga (eds.). 2020. Między lingwistyka a pedagogika. Konteksty glottodydaktyczne i pedeutologiczne. Torun: Wydawnictwo Adam Marszałek.

Gębal, Przemysław E. and Władysław T. Miodunka. 2020. Dydaktyka i metodyka nauczania języka polskiego jako obcego i drugiego. Warsaw: Wydawnictwo Naukowe PWN.

Giroux, Henry. 1983. Theory and Resistance in Education: A Pedagogy for the Opposition. South Hadley, MA: Bergin \& Garvey.

Grucza, Franciszek. 1978. "Glottodydaktyka, jej zakres i problemy." Przeglad Glottodydaktyczny 1:7-12.

Huhta, Marjatta et al. 2013. Needs Analysis for Language Course Design: A Holistic Approach to ESP. Cambridge: Cambridge University Press.

Klus-Stańska, Dorota. 2018. Paradygmaty dydaktyki. Myśleć teoria o praktyce. Warsaw: Wydawnictwo Naukowe PWN.
Koller, Hans-Christoph. 1999. "Lesarten. Über das Geltendmachen von Differenzen im Forschungsprozeß." Zeitschrift für Erziehungswissenschaft 2:195-209.

Kopytowska, Monka and Łukasz Kumięga. 2017. "Krytyczna analiza dyskursu: konteksty, problemy, kierunki rozwoju." Pp. 177-207 in Analiza dyskursu publicznego. Przeglad metod i perspektyw badawczych, edited by M. Czyżewski et al. Warsaw: Wydawnictwo Sedno.

Kumiega, Łukasz. 2020a. “Berufsbezogene Sprachbildung und Diskurs. Theoretische und methodologische Verortungen." Pp. 67-77 in Sprache und Gesellschaft. Theoretische und empirische Kontexte der Linguistik, edited by J. Szczęk and Ł. Kumięga. Berlin: Peter Lang.

Kumięga, Łukasz. 2020b. “Edukacja zawodowo-językowa w Niemczech w świetle krytycznej i postfoucaultowskiej analizy dyskursu." Pp. 14-32 in Między lingwistyka a pedagogika. Konteksty glottodydaktyczne i pedeutologiczne, edited by P. E. Gębal and Ł. Kumięga. Toruń: Wydawnictwo Adam Marszałek.

Kumiega, Łukasz and Monika Nawracka. 2020. “Migracje a edukacja językowa w Polsce. Zarys projektu badawczego." Pp. 66-80 in Tradycyjne podejście i nowe perspektywy w nauczaniu języków obcych. Aspekty, metody, realizacje, edited by E. Bieńkowska-Kajko, E. Mężyk, and B. Stefanowicz. Gliwice: Wydawnictwo Politechniki Śląskiej.

Kwieciński, Zbigniew. 2007. "Potrzeba alfabetyzacji krytycznej." Pp. 27-33 in Edukacja, moralność, sfera publiczna. Materiały z VI Ogólnopolskiego Zjazdu Pedagogicznego PTP, edited by J. Rutkowiak, D. Kubinowski, and M. Nowaka. Lublin: Oficyna Wydawnicza Verba.

Lewicka, Grażyna. 2007. Glottodydaktyczne aspekty akwizycji języka drugiego a konstruktywistyczna teoria uczenia się. Wroclaw: Atut.

Nawracka, Monika. 2020. Nauczanie języka polskiego jako obcego w perspektywie refleksyjnej i kulturowej. Cracow: Księgarnia Akademicka.

Nowicka, Magdalena. 2016. "Postfoucaultowska analiza dyskursu - problemy i szanse dydaktyczne." Pp. 159-181 in Jak analizować dyskurs? Perspektywy dydaktyczne, edited by W. Czachur, A. Kulczyńska, and Ł. Kumięga. Cracow: Universitas.

Ostrowicka, Helena. 2017. Przemyśleć z Michelem Foucaultem edukacyjne dyskursy o młodzieży. Dyspozytyw i urzadzanie. Cracow: Oficyna Wydawnicza „Impuls."

Pfeiffer, Waldemar. 2001. Nauka jezzyków obcych. Od praktyki do praktyki. Poznan: Wydawnictwo Wagros. 
Piekot, Tomasz and Grzegorz Zarzeczny. 2010. "Między zdrowym rozsądkiem a polityczną poprawnością - polskie podręczniki do nauczania języka polskiego jako obcego oczami cudzoziemców." Acta Universitatis Lodziensis. Kształcenie Polonistyczne Cudzoziemców 17:517-528.

Reisigl, Martin. 2010. “Dyskryminacja w dyskursach." Tekst i Dyskurs = Text und Diskurs 3:27-61.

Rylke, Hanna. 1984. "Drugi program w szkole. Rola osobistego wymiaru w pracy nauczyciela." Kwartalnik Pedagogiczny 1:75-85.

Sennett, Richard. 1998. The Corrosion of Character: The Personal Consequences of Work in the New Capitalism. London, New York: W. W. Norton \& Company.

Stankiewicz, Katarzyna and Anna Żurek. 2016. “Der heimliche Lehrplan im DaF Unterricht.” Zielsprache Deutsch 2:39-51.

Stachowiak, Jerzy. 2013. “Pedagogizacja medialna i wzór przedsiębiorcy samego siebie." Societas/Communitas 2(16):141-161.

Szkudlarek, Tomasz. 2010. “Wyzwanie pedagogiki krytycznej." Pp. 9-48 in Wyzwania pedagogiki krytycznej i antypedagogi- $k i$, edited by B. Śliwerski and T. Szkudlarek. Cracow: Oficyna Wydawnicza Impuls.

Śliwerski, Bogusław. 2015. Edukacja (w)polityce. Polityka (w)edukacji. Cracow: Oficyna Wydawnicza Impuls.

Vogt, Karin. 2011. Fremdsprachliche Kompetenzprofile: Entwicklung und Abgleichung von GeR-Deskriptoren für Fremdsprachenlernen mit einer beruflichen Anwendungsorientierung. Tübingen: Narr Verlag.

Wilczyńska, Weronika. 1999. Uczyć się czy być nauczanym: o autonomii w przyswajaniu języka obcego. Warsaw: Wydawnictwo Naukowe PWN.

Yildirim-Krannig, Yeliz. 2014. Kultur zwischen Nationalstaatlichkeit und Migration. Bielefeld: transcript Verlag.

Zarzycka, Grażyna. 2000. “Etnocentryzm, polonocentryzm, wielokulturowość, wielogłosowość... - opis orientacji obecnych w nauczaniu języków obcych." Pp. 69-81 in Polonistyka w świecie. Nauczanie języka i kultury polskiej studentów zaawansowanych, edited by J. Mazur. Lublin: Wydawnictwo UMCS.

Żylińska, Marzena. 2009. "Konstruktywistyczna dydaktyka języków obcych." Języki Obce w Szkole 1:5-14.

\section{Citation}

Kumięga Łukasz (2020) "Discourse, Critique and Subject in Vocational Language Education in Germany: An Outline of the Concept of Critical Foreign Language Didactics." Przeglad Socjologii Jakościowej 16(4):126-145. Retrieved Month, Year (www. przegladsocjologiijakosciowej.org). DOI: http://dx.doi.org/10.18778/1733-8069.16.4.07

\section{Dyskurs, krytyka i podmiot w edukacji zawodowo-językowej w Niemczech. Zarys koncepcji krytycznej dydaktyki języków obcych}

Abstrakt: Celem artykułu jest próba włączenia perspektywy krytyczno-dyskursywnej do refleksji nad edukacją zawodowo-językową w Niemczech i naszkicowanie zrębów krytycznej dydaktyki języków obcych, czerpiącej z krytycznej i postfoucaultowskiej analizy dyskursu. Pierwsza część artykułu to rekonstrukcja uwikłania edukacji zawodowo-językowej w szereg kontekstów (politycznych, migracyjnych i integracyjnych). Krytyczna dydaktyka języków obcych, stanowiąca transformatywną odmianę dydaktyki językowej, mająca za przedmiot swoich dociekań edukację zawodowo-językową, postrzegana będzie jako program badawczy nawiązujący do refleksji nad edukacją i wychowaniem (w ramach pedagogiki krytycznej), nad nauczaniem i uczeniem się (w ramach dydaktyki ogólnej o nachyleniu krytycznym) oraz nad edukacją językową i jej specyfiką w nauczaniu i uczeniu się poszczególnych języków (w ramach dydaktyki języków obcych). W ostatniej części artykułu przedstawione zostaną implikacje metodologiczne poprzez wskazanie potencjalnych kierunków i poziomów analizy edukacji zawodowo-językowej oraz próba ich dalszej specyfikacji zmierzająca w kierunku krytycznej analizy formowania podmiotu oraz form subiektyfikacji.

Słowa kluczowe: dydaktyka języków obcych, krytyczna analiza dyskursu, postfoucaultowska analiza dyskursu, formowanie podmiotu, formy subiektyfikacji 